\title{
PENERAPAN METODE VALUE CHAIN DAN FOUR STAGE LIFE CYCLE UNTUK MENENTUKAN KANDIDAT APLIKASI PADA LABORATORIUM ITCC STT-PLN
}

\author{
Hendra Jatnika, Luqman, Dewi Arianti Wulandari \\ Jurusan Teknik Informatika \\ Sekolah Tinggi Teknik PLN Jakarta \\ Email :h.jatnika.sttpln@gmail.com
}

\begin{abstract}
Strategies and policies in a profit oriented organization also have a social mission (public service) that prioritizes customer service. The development of information systems and information technology will have an impact on the increasingly competitive competition, this is true also in the world of seretifikasi demands the manager to build and develop information systems in helping business activities, achieve organizational goals and services for stakeholders, especially those related to data, information, technology and application, found some cases of information system management failure in achieving organizational goals (objective) because the utilization is not in accordance with the direction and objectives of the organization Value added chain method, which is to describe how to see the business as a chain of activities that change input to output while Four Stage Life Cycle Business System Planning (BSP) is a tool used to determine the derivatives of business functions and application candidates associated with the products / services provided by business functions. ITCC (Information Technology Certification Center) STT PLN is a laboratory that handles several certification programs both international scale, it is necessary to align the utilization of information systems and information technology in accordance with the direction and purpose of college, so that required application and technology and implementation plan of the architecture has been created to support business activities for the achievement of the organization's mission.
\end{abstract}

Keywords: ITCC,BSP, Value added chain, STT PLN, Four Stage Life Cycle

\begin{abstract}
ABSTRAK
Strategi dan kebijakan dalam suatu organisasi yang profit oriented juga mempunyai misi sosial (public service) yang mengutamakan pada layanan konsumen. Perkembangan sistem informasi dan teknologi informasi akan berdampak pada persaingan yang semakin kompetitif, hal ini berlaku juga di dunia seretifikasi menuntut pihak pengelola untuk membangun dan mengembangkan sistem informasi dalam membantu aktifitas bisnis, mencapai tujuan organisasi dan layanan bagi stake holder terutama yang berhubungan dengan data, informasi, teknologi dan aplikasi, ditemukan beberapa kasus pengelolaan sistem informasi mengalami kegagalan dalam mencapai tujuan (objective) organisasi karena pemanfaatan ini tidak sesuai dengan arah dan tujuan organisasi Metode value added chain, yaitu untuk mendeskripsikan cara melihat bisnis sebagai rantai aktifitas yang mengubah input menjadi output sedangkan Four Stage Life Cycle Business System Planning (BSP) adalah tool yang digunakan untuk menentukan turunan dari fungsi bisnis dan kandidat aplikasi yang terkait dengan produk/layanan yang diberikan oleh fungsi bisnis. ITCC (Information Technology Certification Center) STT PLN adalah laboratorium yang menangani beberapa program sertifikasi baik itu berskala internasional, diperlukan adanya keselarasaan pemanfaatan sistem informasi dan teknologi informasi yang sesuai dengan arah dan tujuan perguruan tingggi, sehingga diperlukan aplikasi dan teknologi serta rencana implementasi dari arsitektur yang telah dibuat untuk mendukung aktivitas bisnis demi pencapaian misi organisasi.
\end{abstract}

Kata kunci: ITCC, Value added chain, STT-PLN, Four Stage Life Cycle

\section{PENDAHULUAN}

\subsection{Latar Belakang}

Perkembangan Information System (IS) pada masa Era Masayarat Ekonomi Asean (MEA) yang berkembang pesat akan sangat berdampak pada strategi dan kebijakan dalam suatu organisasi (enterprise) baik yang berorientasi pada laba (profit oriented) ataupun lembaga yang selain profit oriented juga mempunyai misi sosial (public services). Pemanfaatan teknologi dan sistem informasi yang tepat dan selaras dengan tujuan organisasi akan memberikan dampak yang sangat penting dalam memenangkan persaingan yang semakin kompetitif baik di dunia usaha maupun dunia pendidikan.

Persaingan yang semakin kompetitif menuntut pihak pengelola untuk mengembangkan atau membangun sistem informasi dalam membantu aktifitas bisnis untuk mencapai tujuan organisasi dan sebagai layanan bagi stake holder terutama yang berhubungan dengan data, informasi, 
teknologi dan aplikasi. Pengelolaan terhadap data dan informasi yang baik akan memberikan akses yang luas terhadap jaringan data yang terhubung secara global, terkait hal tersebut kami bermaksud melakukan penelitian dengan judul : Penerapan metode Value chain dan Four Stage Life Cycle untuk menentukan kandidat aplikasi pada Laboratorium ITCC STT-PLN.

\subsection{Rumusan Masalah}

Berdasarkan uraian latar belakang diatas, penulis membuat rumusan masalah Bagaimana menerapkan metode Metode Value chain dan Four Stage Life Cycle untuk menentukan kandidat aplikasi pada Laboratorium ITCC STT-PLN

\subsection{Tujuan Penelitian}

Tujuan penelitian ini adalah menghasilkan suatu pedoman perencanaan berikut :

1. Menerapkan metode Metode Value chain dan Four Stage Life Cycle untuk menentukan aplikasi yang tepat diterapkan di Laboratorium ITCC STT-PLN

2. Mengetahui kandidat kebutuhan aplikasi ITCC STT-PLN yang dapat digunakan menetukan arah kebijakan organisasi.

3. Memberikan rekomendasi pengembangan sistem secara komputerisasi bagi Laboratorium ITCC STT-PLN dalam membantu aktifitas-aktifitas bisnis.

\subsection{Manfaat Penelitian}

Manfaat dari penelitian ini adalah dapat menjadi alternatif dalam menentukan pengembangan sistem serta teknologi informasi bagi Laboratorium ITCC STT-PLN.

\section{LANDASAN TEORI}

\subsection{Value Chain Michael E. Porter}

Fungsi dari value added chain, menurut Michael E. Porter yaitu untuk mendeskripsikan cara melihat bisnis sebagai rantai aktifitas yang mengubah input menjadi output sehingga memiliki nilai bagi pelanggan (Porter, E Michael, 1985).

Value chain membagi dalam dua kategori, yaitu:

1. Primary activities, (line functions) merupakan aktifitas utama dari organisasi yang melibatkan aktifitas-aktifitas sebagai berikut:

a. Inbound Logistics, pada bagian ini terkait dengan penerimaan, penyimpanan, dan pendistribusian input menjadi produk.

b. Operations, semua aktifitas yang terkait dengan pengubahan input menjadi bentuk akhir dari produk, seperti produksi, pembuatan, pemaketan, perawatan peralatan, fasilitas, operasi, jaminan kualitas, proteksi terhadap lingkungan.

c. Outbond Logistics, aktifitas yang terkait dengan pengumpulan, penyimpanan, distribusi secara fisik atau pelayanan terhadap pelanggan. d. Marketing and Sales, aktifitas yang terkait dengan pembelian produk dan layanan oleh pengguna dan mendorong untuk dapat membeli produk yang dibuat. Memiliki rantai nilai khusus, antara lain :

1) Marketing management

2) Advertising

3) Sales force administration

4) Sales force operations

5) Technical literature

6) Promotion

e. Service, aktifitas yang terkait dengan penyediaan layanan untuk meningkatkan atau merawat nilai dari suatu produk, seperti instalasi, perbaikan, pelatihan, suplai bahan, perawatan dan perbaikan bimbingan teknis.

2. Secondary activities, (staff atau fungsi overhead) merupakan aktifitas pendukung yang membantu aktifitas utama. Secondary activities melibatkan beberapa bagian/fungsi, antara lain:
a. Firm infrastructure, merupakan aktifitas, biaya, dan aset yang berhubungan dengan manajemen umum, accounting, keuangan, keamanan dan keselamatan sistem informasi, serta fungsi lainnya.

b. Human Resources Management, terdiri dari aktifitas yang terlibat seperti penerimaan, dengar pendapat, pelatihan, pengembangan, dan kompensasi untuk semua tipe personil, dan mengembangkan tingkat keahlian pekerja.

c. Research, Technology, and System Development, aktifitas yang terkait dengan biaya yang berhubungan dengan produk, perbaikan proses, perancangan peralatan, pengembangan perangkat lunak komputer, sistem telekomunikasi, kapabilitas basis data baru, dan pengembangan dukungan sistem berbantuan komputer.

d. Procurement, terkait dengan fungsi pembelian input yang digunakan dalam value chain organisasi.

\subsection{Four Stage Life Cycle Business System} Planning (BSP)

Tool yang digunakan untuk menentukan turunan dari fungsi bisnis yang terkait dengan produk/layanan yang diberikan oleh fungsi bisnis (ICH Architecture Resource Center, 2008).

Ada empat siklus yang digunakan, yaitu antara lain:

1. Tahap I, Requirements, planning, measurements and control

Merupakan tahap untuk menentukan berapa banyak produk/layanan yang dibutuhkan, rencana untuk mendapatkannya, dan pengukuran serta kontrol yang digunakan.

2. Tahap II, Acquisition

Merupakan tahap untuk mengembangkan produk / layanan atau untuk mendapatkan 
sumber daya yang akan dipergunakan untuk kegiatan pengembangan.

3. Tahap III, Stewardships

Merupakan tahap untuk membentuk, mempertajam, memodifikasi, atau merawat dukungan sumber daya dan untuk menyimpan atau menelusuri produk atau layanan.

4. Tahap IV, Retirement

Merupakan tahap keputusan akhir dari tanggung jawab organisasi untuk suatu produk atau layanan atau sinyal yang menyatakan akhir dari penggunaan suatu sumber (resource).

\subsection{Manajemen TI dalam organisasi}

(Ward, John and Peppard, Joe., Strategic Planning for Information System, John Wiley \& Sons, Inc., 2002) mereka menggambarkannya dalam bentuk tiga-model tahapan sebagai berikut :

\section{Pengiriman}

Masalah sistem infomasi terutama internal meningkatkan kemampuan untuk memberikan dan mendukung sistem dan teknologi. Mencapai top kredibilitas manajemen sebagai fungsi yang berharga merupakan tujuan utama. Ini berarti meningkatkan kinerja pengiriman, belum tentu providing pengguna dengan apa yang mereka butuhkan.

2. Reorientasi

Menjalin hubungan baik dengan bisnis utama fungsi, tuntutan bisnis pendukung melalui penyediaan berbagai layanan sebagai kemampuan komputasi menyebar melalui bisnis. Fokus isu diperluas di luar departemen 'DP' dan tujuan utamanya adalah memberikan layanan yang bernilai bagi semua bisnis fungsi manajemen area yang berbeda akan menguntungkan secara berbeda denganmemperhatikan pentingnya bisnis.

3. Reorganisasi

Tingkat kesadaran tinggi diciptakan baik 'lokal' di Indonesia area bisnis dan 'terpusat' dalam manajemen senior menciptakan tampilan awal dan model IS / IT dalam Organisasi

\subsection{Entity-Relationship Diagram (E-R Diagram)}

Model diagram E-R adalah model diagram yang didasarkan pada sebuah persepsi dunia nyata yang terdiri dari obyek dasar yang disebut entitas (entities), dan hubungannya (relationship) diantara entitas tersebut. E-R diagram ini dikembangkan untuk menjembatani kegiatan perancangan basis data dengan menggunakan skema entrprise, yang mempresentasikan seluruh struktur logic dari basis data (Silberschatz

Abraham, Korth Henry F, Sudarshan S, 2002) E-R diagram sangat berguna untuk memetakan maksud dan interaksi dunia nyata dari enterprise ke dalam skema konseptual. Ada tiga konsep dasar dari penggunaan $\mathrm{E}-\mathrm{R}$ diagram yaitu:

Contoh penggunaan E-R Diagram:

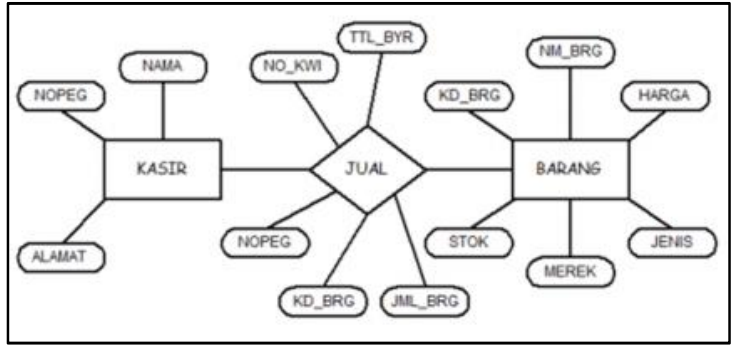

Gambar 2.1 Penggunaan ER-Diagram

\section{METODOLOGI PENELITIAN}

Metode Value Chain Analysis (VCA) adalah rangkaian kegiatan yang dilakukan suatu perusahaan untuk menghasilkan produk atau jasa. Kumpulan aktivitas atau kegiatan dalam sebuah perusahaan yang dilakukan untuk mendesain, memproduksi, memasarkan, mengirimkan, dan mendukung keberadaan produk terangkum dalam sebuah analisa rantai nilai. Jadi, VCA bisa dikatakan sebagai pisau analisa yang bisa digunakan untuk membedah sebuah proses bisnis. Dengan value chain, perusahaan bisa melakukan identifikasi mengenai proses kunci apa yang penting, dan proses mana yang sekadar pendukung. Untuk memahami bagaimana untuk melakukan analisis rantai nilai, bisnis harus terlebih dahulu tahu apa rantai nilainya. Sebuah rantai nilai adalah berbagai kegiatan - termasuk desain, produksi, pemasaran dan distribusi - usaha melalui untuk membawa produk atau layanan dari konsepsi untuk pengiriman. Bagi perusahaan yang memproduksi barang, rantai nilai dimulai dengan bahan baku yang digunakan untuk membuat produk mereka, dan terdiri dari segala sesuatu yang ditambahkan ke dalamnya sebelum dijual ke konsumen. Michael E. Proter dari Harvard Business School merupakan orang pertama yang memperkenalkan konsep value chain. la mulai membahas konsep rantai nilai dalam bukunya "Competitive Advantage: Creating and Sustaining Superior Performance" yang diluncurkan tahun 1985 lalu. Porter, juga mengembangkan Five Forces Model yang banyak digunakan oleh perusahaan untuk mengetahui seberapa baik mereka dapat bersaing di pasar saat ini. Menurut Porter, keunggulan kompetitif tidak akan dapat dipahami dengan melihat perusahaan secara keseluruhan. "Hal ini berasal dari banyaknya kegiatan yang berbeda yang dilakukan di suatu perusahaan dalam merancang, memproduksi, pemasaran, mengirimkan, dan mendukung suatu produk. Masing-masing kegiatan ini dapat memberikan kontribusi dengan posisi biaya masingmasing di perusahaan dan menciptakan dasar untuk diferensiasi," papar Porter.

Analisis rantai nilai atau Value Chain Analysis (VCA) adalah rangkaian kegiatan yang dilakukan suatu perusahaan untuk menghasilkan produk atau jasa. Kumpulan aktivitas atau kegiatan dalam sebuah perusahaan yang dilakukan untuk mendesain, memproduksi, 
memasarkan, mengirimkan, dan mendukung keberadaan produk terangkum dalam sebuah analisa rantai nilai. Jadi, VCA bisa dikatakan sebagai pisau analisa yang bisa digunakan untuk membedah sebuah proses bisnis. Dengan value chain, perusahaan bisa melakukan identifikasi mengenai proses kunci apa yang penting, dan proses mana yang sekadar pendukung. Untuk memahami bagaimana untuk melakukan analisis rantai nilai, bisnis harus terlebih dahulu tahu apa rantai nilainya. Sebuah rantai nilai adalah berbagai kegiatan - termasuk desain, produksi, pemasaran dan distribusi - usaha melalui untuk membawa produk atau layanan dari konsepsi untuk pengiriman. Bagi perusahaan yang memproduksi barang, rantai nilai dimulai dengan bahan baku yang digunakan untuk membuat produk mereka, dan terdiri dari segala sesuatu yang ditambahkan ke dalamnya sebelum dijual ke konsumen. Michael E. Proter dari Harvard Business School merupakan orang pertama yang memperkenalkan konsep value chain. la mulai membahas konsep rantai nilai dalam bukunya "Competitive Advantage: Creating and Sustaining Superior Performance" yang diluncurkan tahun 1985 lalu. Porter, juga mengembangkan Five Forces Model yang banyak digunakan oleh perusahaan untuk mengetahui seberapa baik mereka dapat bersaing di pasar saat ini. Menurut Porter, keunggulan kompetitif tidak akan dapat dipahami dengan melihat perusahaan secara keseluruhan. "Hal ini berasal dari banyaknya kegiatan yang berbeda yang dilakukan di suatu perusahaan dalam merancang, memproduksi, pemasaran, mengirimkan, dan mendukung suatu produk. Masing-masing kegiatan ini dapat memberikan kontribusi dengan posisi biaya masingmasing di perusahaan dan menciptakan dasar untuk diferensiasi," papar Porter.

Berdasarkan Learn Marketing, kalimat Porter menunjukkan bahwa kegiatan dalam sebuah organisasi juga memasukkan unsur nilai pada layanan dan produk yang dihasilkan perusahaan. Artinya semua kegiatan ini harus dijalankan pada tingkat optimal jika organisasi ingin mendapatkan keuntungan kompetitif yang nyata. Jika mereka berjalan secara efisien, nilai yang diperolehpun harus melebihi biaya yang dikeluarkan. Misalnya, pelanggan selalu kembali ke perusahaan dan bertransaksi secara bebas dan sukarela. Dengan VCA, perusahaan dapat melakukan semacam business reengineering. Ini untuk membuat sebuah operasi bisnis menjadi lebih efisien dan mampu memberikan value added yang optimal.

Value Chain menjadi sebuah blue print atau benang merah suatu bisnis. Ada enam fungsi bisnis dari pembuatan rantai nilai, yaitu:

1. Logistik Masuk (Inbound Logistics), adalah aktivitas atau kegiatan yang dihubungkan dengan penerimaan, penyimpanan dan penyebaran input/bahan baku, seperti penanganan bahan baku, pergudangan, kontrol inventory, jadwal kendaraan dan pengembalian kepada supplier.

2. Operasional (Operations), adalah kegiatan yang dihubungkan dengan mengubah input atau bahan baku menjadi bentuk produk akhir, seperti permesinan, pengemasan, perakitan, perawatan perlengkapan, testing, pencetakan dan yang lainnya yang berkaitan dengan prose operasi atau produksi.

3. Logistik Logistics), adalah kegiatan yang diasosiasikan dengan pengumpulan, penyimpanan dan distribusi produk ke pembeli, seperti pergudangan produk jadi, penanganan material, operasi pengiriman, proses pemesanan dan penjadwalan.

4. Pemasaran dan penjualan (Marketing and Sales), adalah kegiatan dalam membujuk atau menarik pembeli untuk membeli, seperti pengiklanan, promosi, tenaga penjual, quota dan harga.

5. Pelayanan (Service), adalah kegiatan yang diasosiasikan dengan penyediaan layanan untuk meningkatkan dan mempertahankan nilai produk, seperi instalasi, perbaikan, pelatihan dan penambahan produk.

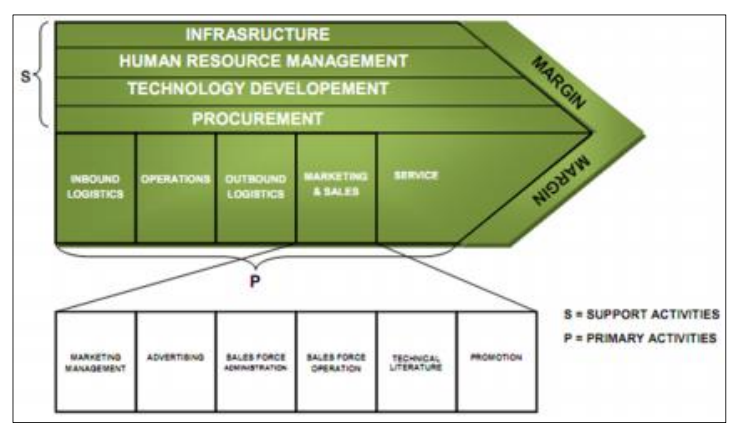

Gambar 3. 1 Metodologi value added chain, menurut Michael E. Porter

Dalam setiap kategori kegiatan/aktivitas, baik itu yang utama maupun yang pendukung, ada tiga jenis kegiatan yang memiliki peran berbeda dalam kegiatan tersebut, yaitu:

1. Langsung (direct), aktivitas yang melibatkan langsung dalam pembuatan nilai kepada pembeli, seperti perakitan, iklan, desain produk, rekrutmen dan lain sebagainya.

2. Tidak langsung (indirect), aktivitas yang memungkinkan untuk melakukan kegiatan langsung secara berkelanjutan, seperti perawatan, penjadwalan, administrasi penelitian dan lain sebagainya.

3. Jaminan kualitas (Quality Assurance), adalah aktivitas yang menjamin kualitas dari aktivitas lain seperti, monitoring, inpeksi, testing, pemeriksaan dan lain sebagainya.

Proses mengatur semua kegiatan ini sehingga mereka dapat dianalisis dengan baik disebut manajemen rantai nilai. Tujuan dari manajemen rantai nilai adalah untuk memastikan bahwa orangorang yang bertanggung jawab atas setiap tahap dari rantai nilai berkomunikasi dengan satu sama lain, untuk membantu memastikan produk semakin di tangan pelanggan sebagai mulus dan secepat mungkin. 
Sedangkan kegiatan pendukung (support activities) secara umum, terbagi dalam 4 kategori kegiatan, yaitu:

1. Procurement atau pengadaan, berkaitan dengan bagaimana bahan baku untuk produk yang diperoleh. Ini mengacu pada fungsi pembelian seperti pembelian bahan mentah, persedian dan jenis jenis barang lainnya yang dapat dijadikan aset seperti mesin-mesin, perlengkapan laboratorium, kantor dan bangunan.

2. Technology Development atau pengembangan teknologi, terdiri dari berbagai kegiatan yang dapat dikelompokkan ke dalam usaha untuk meningkatkan produk dan proses. Pengembangan teknologi sangat penting untuk keunggulan kompetitif dalam semua industri.

3. Human Resource Management, pengelolaan sumberdaya manusia meliputi kegiatan rekrutmen, pelatihan, pengembangan SDM. Hal ini berkaitan dengan kegiatan dalam mempekerjakan dan mempertahankan karyawan yang tepat untuk membantu desain, membangun dan memasarkan produk.

4. Firm Infrastructure, aktivitas infrastruktur perusahaan terdiri dari sejumlah aktivitas termasuk pengelolaan umum, perencanaan, keuangan, akuntansi, dan manajemen kualitas.

\section{HASIL DAN PEMBAHASAN}

Hasil yang yang diharapkan nantinya dalam penelitian ini adalah menghasilkan suatu pedoman perencanaan berikut :

1. Dapat menentukan aplikasi yang tepat diterapkan di Laboratorium ITCC STT-PLN

2. Dapat Mengetahui kandidat kebutuhan aplikasi ITCC STT-PLN yang dapat digunakan menetukan arah kebijakan organisasi.

3. Memberikan rekomendasi pengembangan sistem secara komputerisasi bagi Laboratorium ITCC STT-PLN dalam membantu aktifitas-aktifitas bisnis.

\section{Gambaran Struktur Organisasi}

Struktur organisasi bertujuan untuk membarikan gambaran tugas, wewenang dan tanggung jawab dari setiap unit yang ada dalam organisasi Struktur Laboratorium ITCC STT-PLN seperti gambar di bawah ini.

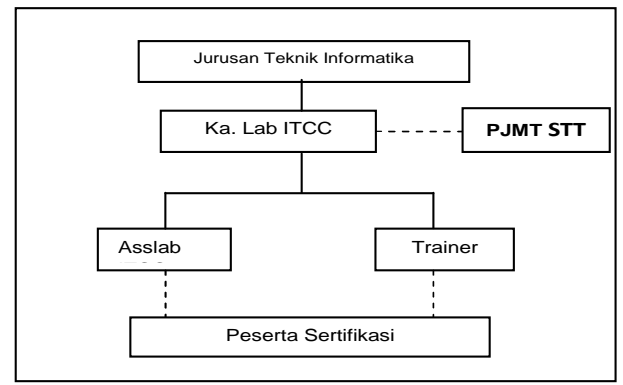

Gambar 4.1 Struktur Organisasi ITCC STT-PLN

\section{Menentukan Area Bisnis}

Laboratorium ITCC STT-PLN Untuk area fungsi dan hirarki bisnis laboratorium ITCC STTPLN memiliki aktivitas yang berpedoman pada Visi dan Misi Organisasi serta dukungan dari aktivitas lainnya terutama dari institusi STT-PLN seperti :

a. Jurusan Teknik Informatika STT-PLN sebagai penyedia Fasilitas Laboratorium ITCC

b. Bidang administrasi akademik (BAAK) STTPLN sebagai pusat pengelola data mahasiwa

c. Pusat dan Pengembangan Sistem Informasi (PPSI) STT-PLN sebagai pengelola infrastruktur sistem informasi terintegrasi di STT-PLN

d. Bidang Kerjasama dan Usaha serta PJMT yang memberikan kewenangan untuk membuka peluang mengadakan sertifikasi dengan pihak eksternal

Identifikasi aktivitas utama dan pendukung dari laboratorium ITCC STT-PLN dapat ditunjukan dengan menggunakan rantai nilai (value chain) dari Michael E. Porter yang tampak seperti di bawah ini

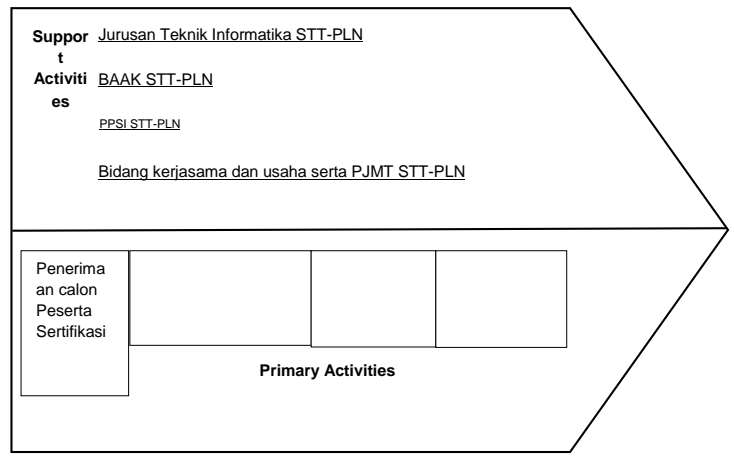

Gambar 4.2 value chain Lab ITCC

Tabel 4.1 Deskripsi Fungsi bisnis

\begin{tabular}{|c|c|c|}
\hline No & Fungsi Bisnis & Deskripsi \\
\hline E. & $\begin{array}{l}\text { Pendaftaran Peserta } \\
\text { Setifikasi (PPS) }\end{array}$ & $\begin{array}{l}\text { A. Formulir registrasi peserta sertifikasi } \\
\text { B. Tata cara registrasi }\end{array}$ \\
\hline F. & $\begin{array}{l}\text { Pemilihan Program } \\
\text { Sertifikasi }\end{array}$ & C. Daftar pilihan program sertifikasi \\
\hline G. & Pengelolaan data Trainer & $\begin{array}{ll}\text { D. } & \text { Formulir kesediaan trainer } \\
\text { E. } & \text { Formulir jadwal trainer } \\
\text { F. } & \text { Formulir absensi trainer }\end{array}$ \\
\hline H. & $\begin{array}{l}\text { Penjadwalan training } \\
\text { peserta sertifikasi }\end{array}$ & $\begin{array}{l}\text { G. Pembuatan absensi jadwal training peserta } \\
\text { H. Rekap data training peserta }\end{array}$ \\
\hline I. & $\begin{array}{l}\text { Penjadwalan ujian peserta } \\
\text { sertifikasi }\end{array}$ & $\begin{array}{ll}\text { I. } & \text { Penetapan jadwal ujian peserta } \\
\text { J. } & \text { Penetapan kelompok ujian peserta }\end{array}$ \\
\hline
\end{tabular}

Pada tahapan ini bertujuan untuk mengetahui posisi bisnis organisasi dengan melakukan analisis terhadap kondisi obyektif organisasi berdasarkan demand dan market share dari organisasi.

Sebagai organisasi dibidang penyelenggaraan sertifikasi yang baru berdiri sesuai dengan dinamika perubahan lingkungan dan perkembangan ilmu dan teknologi yang pesat, maka Laboratorium ITCC STT-PLN harus melakukan perubahan untuk tetap berdiri dan berkembang. Kondisi organisasi sampai saat ini dapat digambarkan sebagai berikut :

a) Memiliki pangsa pasar tersendiri sebagai organisasi yang bergerak dalam bidang sertifikasi

b) Komitmen manajemen yang tinggi terhadap pemanfaatan teknologi informasi dalam 
mendukung aktivitas organisasi, sehingga memberi nilai tambah bagi Laboratorium ITCC STT-PLN

c) Komitmen terhadap perbaikan fasilitas dan layanan informasi, perbaikan terhadap infrastruktur, sarana dan pra sarana ini merupakan suatu kekuatan bagi Laboratorium ITCC STT-PLN

d) Komitmen selalu malakukan evaluasi diri yang bertujuan untuk meningkatkan kepuasan bagi civitas akademika STT-PLN atau peserta sertifikasi dan stake holder.

Untuk area fungsi dan hirarki bisnis ITCC STT-PLN memiliki aktivitas yang berpedoman pada Visi dan Misi Organisasi dan aktivitas ini memerlukan dukungan dari aktivitas lainnya terutama dari institusi STT-PLN seperti bidang akademik (BAAK) sebagai pusat pengelola aktifitas mahasiwa, Pusat dan Pengembangan Sistem Informasi (PPSI) STT-PLN sebagai pengelola sumber data calon peserta sertifikasi dari internal STT-PLN dan dukungan terhadap perangkat teknologi informasi serta semua pihak sumber daya manusia di semua jurusan/program studi di STTPLN. Aktifitas Laboratorium ITCC STT-PLN saat ini dapat dijelaskan sebagai berikut:

a) Proses Training Of Trainer (TOT) Laboratorium ITCC STT-PLN

Aktifitas ini berfokus kepada kerjasama dengan pihak ketiga untuk pelaksaan TOT di Laboratorium ITCC STT-PLN

1) Penjajakan kerjasama dengan pihak ketiga untuk melaksanakan TOT

2) Penetapan calon Trainer Laboratorium ITCC

3) Penjadwalan dan pelaksaanan TOT

4) Laporan TOT

b) Proses penerimaan Pendaftaran Peserta Sertifikasi (PPS)

Aktifitas ini berfokus pada pengelolaan penerimaan pendaftaran peserta sertifikasi

1) Penjadwalan registrasi PPS

2) Penyusunan anggaran training dan ujian sertifikasi

3) Penetapan trainer dan proctor/teknisi sertifikasi

4) Strategi dan sosialisasi jadwal sertifikasi

5) Pengelompokan peserta sertifikasi

6) Perekapan PPS dan laporan PPS

c) Proses pelaksanaan Training

Aktifitas ini berfokus kepada teknis pelaksanaan training kepada peserta sertifikasi sesuai dengan pilihan program tiap peserta.

1) Koordinasi dengan pihak terkait di internal STT-PLN

2) Koordinasi dengan Trainer untuk penjadwalan dan persiapan materi training peserta sertifikasi

3) Administratif pelaksanaan training

d) Proses pelakasanaan ujian Sertifikasi Aktifitas ini berfokus kepada teknis pelaksanaan ujian peserta sertifikasi sesuai dengan pilihan program tiap peserta.
1) Pengecekan perangkat ujian

2) Registrasi peserta ujian sertifikasi sesuai penetapan jadwal

3) Pelaksanaan ujian

4) Pengawasan ujian dan Perekapan hasil ujian

\section{Penggambaran arsitektur sistem Saat ini}

a. Preparasi Koleksi data

Laboratorium ITCC telah memanfaatkan SI dalam mendukung aktivitas bisnisnya, tetapi belum semua aktivitas telah didukung oleh sistem informasi. Oleh karena itu perlu dilakukan inventarisasi terhadap aplikasi, data dan teknologi yang ada dalam lingkungan organisasi ini. Datadata yang berhubungan dengan pengelolaan data peserta sertifikasi internal yaitu dari STT-PLN:

1. Data mahasiswa

2. Data jurusan

3. Data program sertifikasi

4. Data trainer

5. Data jadwal training

6. Data jadwal ujian

7. Data kelulusan ujian

8. Data registrasi peserta

Tabel 4.2 Deskripsi Preparasi Koleksi Data

\begin{tabular}{|c|c|c|c|c|}
\hline No & $\begin{array}{l}\text { Pengolahan } \\
\text { data }\end{array}$ & Field & & Unit Pelaksana \\
\hline 1. & $\begin{array}{l}\text { Administrasi } \\
\text { data peserta }\end{array}$ & $\begin{array}{l}7.1 .1 \\
\\
7.1 .2 \\
7.1 .3 \\
7.1 .4 \\
7.1 .5 \\
7.1 .6 \\
7.1 .7\end{array}$ & $\begin{array}{l}\text { No induk } \\
\text { mahasiswa } \\
\text { atau no } \\
\text { registrasi } \\
\text { Nama peserta } \\
\text { Tempat, } \\
\text { tanggal lahir } \\
\text { Alamat } \\
\text { Jenis kelamin } \\
\text { Email } \\
\text { No Tlp/Hp }\end{array}$ & \multirow[t]{3}{*}{$\begin{array}{l}\text { Bagian } \\
\text { registrasi dan } \\
\text { penjadwalan }\end{array}$} \\
\hline 2. & $\begin{array}{l}\text { Administrasi } \\
\text { Pilihan } \\
\text { program }\end{array}$ & \multicolumn{2}{|c|}{$\begin{array}{ll}\text { a. } & \text { Kode program } \\
\text { b. } & \text { Nama program } \\
\text { c. } & \text { Tingkatan } \\
& \text { program }\end{array}$} & \\
\hline 3. & Penjadwalan & $\begin{array}{l}\text { a. } \\
\text { b. }\end{array}$ & $\begin{array}{l}\text { adwal training } \\
\text { ladwal } \\
\text { ertifikasi }\end{array}$ & \\
\hline 4. & $\begin{array}{l}\text { Administrasi } \\
\text { Data jurusan }\end{array}$ & $\begin{array}{l}\text { a. } \\
\text { b. }\end{array}$ & $\begin{array}{l}\text { Jama jurusan } \\
\text { lumlah } \\
\text { nahasiswa }\end{array}$ & \multirow[b]{2}{*}{$\begin{array}{l}\text { Bagian } \\
\text { administrasi }\end{array}$} \\
\hline 5. & $\begin{array}{l}\text { Administrasi } \\
\text { Data trainer }\end{array}$ & $\begin{array}{l}\text { a. } \\
\text { b. } \\
\text { c. }\end{array}$ & $\begin{array}{l}\text { Kode trainer } \\
\text { Jama trainer } \\
\text { Kompetensi } \\
\text { rainer }\end{array}$ & \\
\hline 6 & $\begin{array}{l}\text { Administrasi } \\
\text { teknis ujian } \\
\text { dan sertifikat }\end{array}$ & $\begin{array}{l}\text { a. } \\
\text { b. }\end{array}$ & $\begin{array}{l}\text { ladwal ujian } \\
\text { ladwal } \\
\text { sengammbilan } \\
\text { sertifikat }\end{array}$ & $\begin{array}{l}\text { Bagian } \\
\text { operasional }\end{array}$ \\
\hline
\end{tabular}

4. Penggunaan sumber daya komputer

1. Pemanfaatan perangkat keras dan perangkat lunak untuk mendukung pengerjaan EAP.

Pemanfaatan perangkat keras meliputi komputer dan printer, scanner dan jaringan, sedangkan perangkat lunak meliputi: sistem operasi dan aplikasi pengolah kata. 
Tabel 4.3 Pemanfaatan Teknologi

\begin{tabular}{|c|c|c|}
\hline No & Fungsi Bisnis & Deskripsi \\
\hline 1. & $\begin{array}{l}\text { Sistem Operasi } \\
\text { sekreatriat }\end{array}$ & $\begin{array}{l}\text { Ms. Windows } 7 \text { dan Ms. } \\
\text { Windows } 10\end{array}$ \\
\hline 2. & $\begin{array}{l}\text { Sistem Operasi pada } \\
\text { Leptop Sertifikasi }\end{array}$ & - Windows 10 \\
\hline 3. & DBMS & - Ms. Excel 2013 \\
\hline 4. & Office Automation & $\begin{array}{l}\text { - Ms Office } 2013 \text { ( Word, } \\
\text { Excel dan Power Point) } \\
\text { - } \quad \text { Adobe Reader }\end{array}$ \\
\hline 5. & Grafis dan Multimedia & $\begin{array}{l}\text { - Corel Draw } \\
\text { - } \text { Adobe Photoshop }\end{array}$ \\
\hline 6. & $\begin{array}{l}\text { PC (Personal } \\
\text { Computer) dan Laptop } \\
\text { Operasional } \\
\text { Sekretariat }\end{array}$ & $\begin{array}{l}\text { - Standar (Compitable) } \\
\text { non Networking }\end{array}$ \\
\hline 7. & $\begin{array}{l}\text { Laptop Operasional } \\
\text { Sertifikasi }\end{array}$ & - Standar Core i3 \\
\hline 8. & Storage & $\begin{array}{ll}\text { - } & \text { Flasdisk } \\
\text { - } & \text { Hardisk Eksternal } \\
\text { - } & \text { DVD RW }\end{array}$ \\
\hline 9. & I/O Device & $\begin{array}{ll}- & \text { Mouse standar } \\
\text { - } & \text { Printer }\end{array}$ \\
\hline 10. & Networking & - Internet \\
\hline 11. & Website & - http://sttpln.ac.id/ \\
\hline
\end{tabular}

\section{Arsitektur dari perangkat teknologi Sekretariat ITCC Saat ini}

Perangkat tenologi informasi di sekretariat ITCC saat ini masih bersifat single user hal ini dikarenakan masih menggunakan perangkat pribadi dan hanya terkoneksi ke internet central di STT PLN. Dengan kondisi seperti itu oerasional tidak dapat maksimal karena :

Arsitektur dari perangkat teknologi Laboratorium ITCC

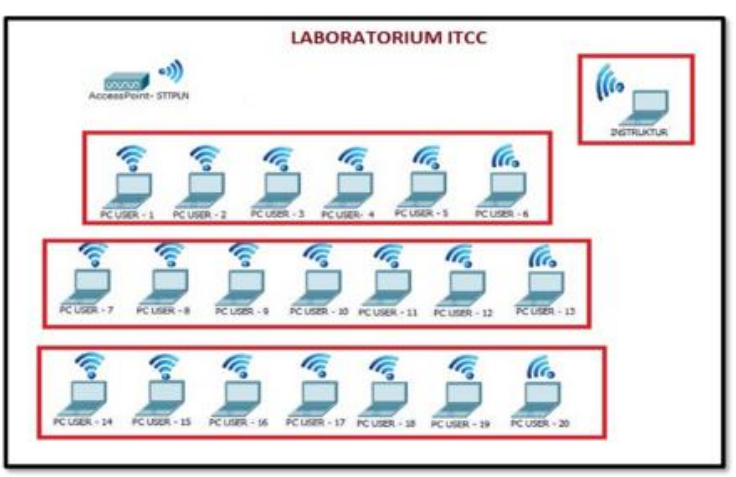

Gambar 5.1 Laboratorium ITCC Saat ini

Perangkat teknologi informasi pada LAB ITCC menggunakan laptop dengan spesifikasi:

\begin{tabular}{|l|l|}
\hline Processor & $\begin{array}{l}\text { Intel } \\
1,70 \mathrm{Ghz} \text { Core TM i3 -4005U CPU }\end{array}$ \\
\hline RAM & $2,00 \mathrm{~GB}$ \\
\hline System Type & 64 -bit OS, X64-Bases Processor \\
\hline Memory & $2048 \mathrm{MB}$ \\
\hline HD & $500 \mathrm{~GB}$ \\
\hline VGA Display & $1088 \mathrm{MB}$ \\
\hline Support & LAN, HDMI, USB \\
\hline OS & Windows 7.0 \\
\hline
\end{tabular}

1. Menentukan aktivitas Utama organisasi

a. Aktifitas penerimaan calon peserta sertifikasi yaitu Penerimaan calon peserta sertifikasi atau pendaftaran peserta sertifikasi (PPS) berhubungan dengan penerimaan data peserta dan bukti pembayaran pilihan program sertifikasi calon peserta

b. Aktifitas pelaksanaan sertifikasi yaitu Penjadwalan sertifikasi berhubungan dengan penelompokan peserta, penjadwalan training, penjadwalan tariner dan jadwal ujian

c. Aktifitas Pemberian sertifikat yaitu pemberian bukti sebagai peserta sertifikasi di laboratorium ITCC STT-PLN

d. Aktifitas Promosi program sertifikasi dan kerjasama berhubungan dengan sosialisasi program sertifikasi beserta sistemnya baik secara internal ataupun eksternal

\section{Menentukan aktifitas pendukung}

a. Jurusan teknik Informatika

Memberikan dukungan dari segi infrastruktur laboratorium ITCC dan kebutuhan operasional

b. BAAK

Memberikan dukungan kebutuhan data peserta sertifikasi internal dan koordinasi penjadwalan aktifitas sehingga tidak berbenturan dengan aktifitas lainnya

c. PPS

Memberikan dukungan terhadap koneksi internet dan infrastruktur jaringan komputer

d. Bidang Kerjasama dan Usaha serta PJMT Memberikan dukungan peluang kerjasama dengan pihak relasi eksternal

\section{Menentukan Fungsi Bisnis menggunakan} tools Four Stage Life Cycles

Untuk mendapatkan gambaran siklus dari setiap aktivitas dari fungsi bisnis organisasi dapat menggunakan tools Four Stage Life Cycles dari IBM Corp

Tabel 4.4 Four Stage Life Cycles Primary Activities

\begin{tabular}{|l|l|l|l|l|}
\hline Stage/Aktivitas & Requirement & Acquisition & Stewardship & Retirement \\
\hline $\begin{array}{l}\text { Penerimaan peserta } \\
\text { sertifikasi (PPS) }\end{array}$ & $\begin{array}{l}\text { Penentuan } \\
\text { kebijakan } \\
\text { penerimaan calon } \\
\text { peserta sertifikasi }\end{array}$ & $\begin{array}{l}\text { Pembentukan panitia } \\
\text { sertifikasi }\end{array}$ & $\begin{array}{l}\text { Penerimaan } \\
\text { calon peserta } \\
\text { sertifikasi }\end{array}$ & Registrasi PPS \\
& $\begin{array}{l}\text { Penyusunan anggaran } \\
\text { pelaksanaan sertifikasi }\end{array}$ & $\begin{array}{l}\text { Pendataan dan } \\
\text { pengelompokan } \\
\text { calon peserta } \\
\text { berdasarkan } \\
\text { program pilihan } \\
\text { sertifikasi }\end{array}$ & \\
\hline
\end{tabular}




\begin{tabular}{|c|c|c|c|c|}
\hline Stage/Aktivitas & Requirement & Acquisition & Stewardship & Retirement \\
\hline $\begin{array}{l}\text { Proses pelaksanaan } \\
\text { sertifikasi }\end{array}$ & $\begin{array}{l}\text { Kebijakan } \\
\text { Perencanaan } \\
\text { pengembangan } \\
\text { program sertifikasi } \\
\text { dan SDM serta } \\
\text { implementasi } \\
\text { program sertifikasi }\end{array}$ & $\begin{array}{l}\text { Pengembangan } \\
\text { program sertifikasi } \\
\text { Pengembangan SDM } \\
\text { Penetapan program dan } \\
\text { jadwal sertifikasi } \\
\text { Penetapan keuangan } \\
\text { pelaksanaan sertifikasi }\end{array}$ & $\begin{array}{l}\text { Penjadwalan } \\
\text { proctor, trainer } \\
\text { dan kelompok } \\
\text { sertifikasi } \\
\text { Pelaksanaan } \\
\text { tarining } \\
\text { Pelaksanaan } \\
\text { ujian } \\
\text { Pelaksanaan } \\
\text { evaluasi } \\
\text { sertifikasi }\end{array}$ & $\begin{array}{l}\text { Rekap SDM pelaksana } \\
\text { program sertifikasi } \\
\text { Rekap peserta training } \\
\text { dan ujian } \\
\text { Penyusunan LPJ } \\
\text { kegiatan sertifikasi }\end{array}$ \\
\hline Pemberian sertifikat & $\begin{array}{l}\text { Kebijakan } \\
\text { pemberian } \\
\text { sertifikat }\end{array}$ & $\begin{array}{l}\text { Penetapan syarat } \\
\text { peserta yang } \\
\text { mendapatkan sertifikat }\end{array}$ & $\begin{array}{l}\text { Pembuatan } \\
\text { sertifikat } \\
\text { Pendataan } \\
\text { peserta yang } \\
\text { mendapatkan } \\
\text { sertifikat }\end{array}$ & $\begin{array}{l}\text { Rekap dan validasi } \\
\text { sertifikat }\end{array}$ \\
\hline $\begin{array}{l}\text { Promosi program } \\
\text { sertifikasi dan } \\
\text { kerjasama }\end{array}$ & $\begin{array}{l}\text { Kebijakan sistem } \\
\text { promosi }\end{array}$ & $\begin{array}{l}\text { Penetapan biaya } \\
\text { program sertifikasi dan } \\
\text { Penetapan sistem } \\
\text { kerjasama }\end{array}$ & $\begin{array}{l}\text { Pembuatan tools } \\
\text { promosi } \\
\text { Pembuatan } \\
\text { model sistem } \\
\text { kerjasama } \\
\text { (MOU) }\end{array}$ & $\begin{array}{l}\text { Promosi dan penjajakn } \\
\text { kerjasama }\end{array}$ \\
\hline
\end{tabular}

Tabel 4.5 Four Stage Life Cycles SupportActivities

\begin{tabular}{|c|c|c|c|c|}
\hline Stage/Aktivitas & Requerement & Acquisition & Stewardship & Retirement \\
\hline $\begin{array}{l}\text { Jurusan teknik } \\
\text { Informatika }\end{array}$ & $\begin{array}{l}\text { Perencanaan } \\
\text { infrastruktur } \\
\text { Laboratorium dan } \\
\text { kebutuhan } \\
\text { administratif }\end{array}$ & $\begin{array}{l}\text { Penetapan infrastruktur } \\
\text { Penetapan kebutuhan } \\
\text { administratif }\end{array}$ & $\begin{array}{l}\text { Pengawasan } \\
\text { operasional } \\
\text { pelaksanaan } \\
\text { sertifikasi }\end{array}$ & $\begin{array}{l}\text { Pelaporan pemanfaatan } \\
\text { laboratorium dan } \\
\text { mendapat pelaporan } \\
\text { administrasi data } \\
\text { peserta sertifikasi }\end{array}$ \\
\hline BAAK & $\begin{array}{l}\text { Perencanaan } \\
\text { kebijakan } \\
\text { akademik untuk } \\
\text { mensertifikasi } \\
\text { mahasiswa STT- } \\
\text { PLN }\end{array}$ & $\begin{array}{l}\text { Penetapan kebijakan } \\
\text { akademik dan data } \\
\text { calon peserta untuk } \\
\text { registrasi sertifikasi }\end{array}$ & $\begin{array}{l}\text { Pelaksanaan } \\
\text { kebijakan } \\
\text { akademik }\end{array}$ & $\begin{array}{l}\text { Mendapat pelaporan } \\
\text { administrasi data } \\
\text { peserta sertifikasi }\end{array}$ \\
\hline PPSI & $\begin{array}{l}\text { Perencanaan } \\
\text { infrastruktur } \\
\text { perangkat } \\
\text { teknologi informasi } \\
\text { laboratorium }\end{array}$ & $\begin{array}{l}\text { Penetapan kebijakan } \\
\text { infrastruktur perangkat } \\
\text { teknologi informasi } \\
\text { laboratorium }\end{array}$ & $\begin{array}{l}\text { Pelaksanaan } \\
\text { kebijakan } \\
\text { infrastruktur } \\
\text { perangkat } \\
\text { teknologi } \\
\text { informasi } \\
\text { laboratorium }\end{array}$ & $\begin{array}{l}\text { Evaluasi kebijakan } \\
\text { infrastruktur perangkat } \\
\text { teknologi informasi } \\
\text { laboratorium }\end{array}$ \\
\hline $\begin{array}{l}\text { Bidang Kerjasama dan } \\
\text { Usaha serta PJMT }\end{array}$ & $\begin{array}{l}\text { Perencanaan } \\
\text { kerjasama dengan } \\
\text { pihak eksternal } \\
\text { dalam } \\
\text { pelaksanaan dan } \\
\text { pengembangan } \\
\text { sertifikasi }\end{array}$ & $\begin{array}{l}\text { Penetapan kebijakan } \\
\text { kerjasama dengan pihak } \\
\text { eksternal dalam } \\
\text { pelaksanaan dan } \\
\text { pengembangan } \\
\text { sertifikasi }\end{array}$ & $\begin{array}{l}\text { Pelaksanaan } \\
\text { kebijakan } \\
\text { kerjasama } \\
\text { dengan pihak } \\
\text { eksternal dalam } \\
\text { pelaksanaan } \\
\text { dan } \\
\text { pengembangan } \\
\text { sertifikasi }\end{array}$ & $\begin{array}{l}\text { Evaluasi Pelaksanaan } \\
\text { kebijakan kerjasama } \\
\text { dengan pihak eksternal } \\
\text { dalam pelaksanaan dan } \\
\text { pengembangan } \\
\text { sertifikasi }\end{array}$ \\
\hline
\end{tabular}

\section{Menentukan kandidat aplikasi berdasarkan fungsi bisnis \\ Berdasarkan Four Stage Life Cycle, maka} dapat diidentifikasi kandidat aplikasi yang akan dibuat guna mendukung aktivitas utama maupun aktivitas pendukung organisasi ke dalam kelompokkelompok aplikasi sesuai dengan aktivitas yang ada menurut value chain. Pengelompokan ini bertujuan untuk melakukan inventarisasi kebutuhan aplikasi berdasarkan aktivitas yang ada sehingga mempermudah bagi organisasi pada saat akan implementasi.

1. Kelompok aplikasi Penerimaan calon peserta sertifikasi

a. Registrasi Peserta sertifikasi Online

b. Registrasi Peserta sertifikasi Onplace

2. Kelompok aplikasi Proses pelaksanaan sertifikasi 
a. Pendataan trainer

b. Pendataan proctor

c. Pendataan program sertifikasi

d. Pendataan kelompok peserta sertifikasi

e. Pembuatan jadwal training

f. Pembuatan jadwal sertifikasi

3. Kelompok aplikasi Pemberian sertifikat

a. Pendataan sertifikat peserta sertifikasi

b. Validasi sertifikan online

c. Validasi sertifikan onplace

4. Kelompok aplikasi Aplikasi promosi dan kerjasama
a. Aplikasi promosi online
b. Aplikasi promosi onplace
c. Aplikasi penawaran kerjasama online

\section{KESIMPULAN}

Kesimpulan ini pada dasarnya merupakan jawaban dari identifikasi yang telah dikembangkan dari hasil implementasi metode yang sudah dilakukan yaitu :

1. Penulis telah menjawab rumusan masalah yang ada

2. Adanya implentasi Penerapan metode Value chain dan Four Stage Life Cycle untuk menentukan kandidat aplikasi pada Laboratorium ITCC STT-PLN

3. Adanya aplikasi terintegrasi dapat memaksimalkan pelayanan ataupun penyebaran informasi-informasi penting baik yang dibutuhkan oleh pihak internal ataupun eskternal

\section{DAFTAR PUSTAKA}

1. IBM, Business System Planning (Information System Planning Guide), International Business Machines Corporation, 1981.

2. Porter, Michael E, Competitive Advantage : Creating and Sustaining Superior Performance for Analyzing Industries and Competitor, 1985

3. Spewak, Steven H,.Steven C.Hill, (1992). Enterprise Architecture Planning : Developing a Blueprint of Data Application and Technology, John Wiley and Sons, Inc.

4. Ward, John and Peppard, Joe., Strategic Planning for Information System, John Wiley \& Sons, Inc., 2002. 